LA-UR- 96-582

Title:

EROSION AND DEPOSITION ON THE PAJARITO PLATEAU,

NEW MEXICO, AND IMPLICATIONS FOR GEOMORPHIC

RESPONSES TO LATE QUATERNARY CLIMATIC CHANGES

APR 1219

1)

Author(s): S. L. Reneau, E. V. McDonald, J. N. Garner,

T. R. Kolbe, J. S. Carney, P. M. Watt,

P. A. Longmire

Submitted to:

New Mexico Geological Society 1996

Fall Field Guidebook

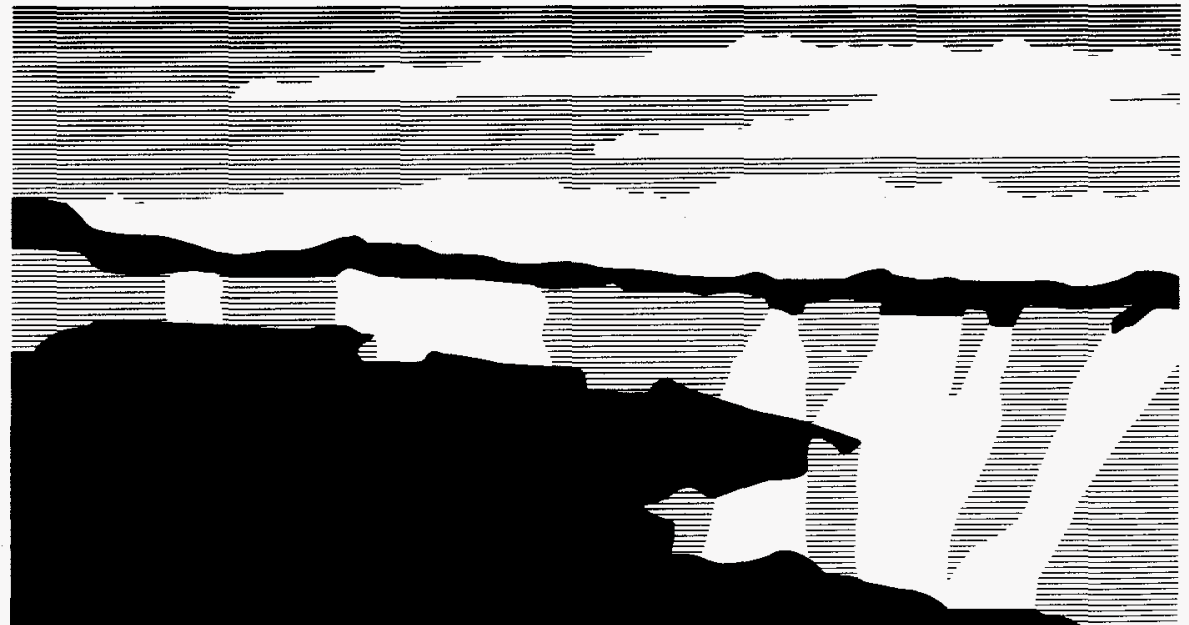

NATIONAL LABORATORY

Los Alamos National Laboratory, an affirmative action/equal opportunity emplơyer, is operated by the University of California for the U.S. Department of Energy under contract W-7405-ENG-36. By acceptance of this article, the publisher recognizes that the U.S. Government retains a nonexclusive, royalty-free license to publish or reproduce the published form of this contribution, or to allow others to do so, for U.S. Government purposes. The Los Alamos National Laboratory requests that the publisher identify this article as work performed under the auspices of the U.S. Department of Energy 


\section{DISCLAIMER}

Portions of this document may be illegible in electronic image products. Images are produced from the best available original document. 


\title{
LA-UR- $96-5.82$
}

Reneau et al. p. 1

\section{EROSION AND DEPOSITION ON THE PAJARITO PLATEAU, NEW MEXICO, AND IMPLICATIONS FOR GEOMORPHIC RESPONSES TO LATE QUATERNARY CLIMATIC CHANGES}

\author{
STEVEN L. RENEAU ${ }^{1}$, ERIC V. MCDONALD 1 , JAMIE N. GARDNER ${ }^{1}$, THOMAS R. \\ KOLBE ${ }^{2}$, JOHN S. CARNEY 3 , PAULA M. WATT ${ }^{4}$, and PATRICK A. LONGMIRE 5
}

${ }^{1}$ Geology and Geochemistry Group, MS D462, Los Alamos National Laboratory, Los Alamos, New Mexico 87545; 2 Woodward-Clyde Federal Services, 500 12th Street, Suite 100, Oakland, California 94607; 3 Department of Geology, Kent State University, Kent, Ohio 44242; 4 Department of Earth and Planetary Sciences, University of New Mexico, Albuquerque, New Mexico 87131; 5 Environmental Geochemistry Group, MS J534, Los Alamos National Laboratory, Los Alamos, New Mexico 87545

Abstract--The gently-sloping mesa tops and adjoining canyons of the Pajarito Plateau contain a diverse record of late Quaternary landscape changes that was probably strongly affected by fluctuations in climate. The streams show considerable variability in their behavior during the Holocene, with some experiencing progressive incision into tuff that was interrupted by periods of lateral cutting and floodplain development, while others experienced progressive aggradation interrupted by episodes of channel cutting into alluvial fills. Available data indicate that many streams were incised below their present level in the late Pleistocene and have subsequently aggraded in the Holocene, and this aggradation was probably due to a major increase in sediment supply within the drainage basins accompanying the Pleistocene-Holocene transition. Although the processes producing such accelerated erosion are not fully understood, they may have been aided by an enhancement of intense summer rainfall in the early Holocene. Widespread erosion has continued into modern times, progressively stripping soils from mesa tops, including welldeveloped soils that are older than 50-60 ka, and exposing tuff bedrock in many areas. Additional effects of climatic change near the Pleistocene-Holocene transition may have included an increased 
influx of eolian sediment onto mesas, accounting for local mesa-top aggradation despite the high erosion rates that have apparently characterized the Holocene.

\section{INTRODUCTION}

The Pajarito Plateau of northern New Mexico contains a rich and diverse record of late Quaternary landscape changes in a variety of geomorphic settings that include gently-sloping mesa tops, steep canyon walls, and canyon bottoms. A broad range of investigations during the past decade, motivated by environmental and seismic hazard concerns, have resulted in examination of the characteristics, stratigraphy, and age of sediments and soils at numerous locations throughout the Plateau. Geochronologic control is provided by $>140$ radiocarbon dates (mostly on disseminated charcoal fragments), supplemented by soil characterization and tephrochronology.

In this paper we first summarize some of the results of recent and ongoing work on late Quaternary deposits on the Pajarito Plateau, illustrating both the complexity of the geomorphic record and some common elements that have been observed in multiple locations. We then use these observations, in combination with other work in the Southwest, to make some inferences about the local geomorphic response to regional climatic changes. Because the geomorphic and paleoclimatic records are fragmentary, and because the relations between large scale climate changes and local variations in precipitation, vegetation, and geomorphic processes are not fully understood, many uncertainties exist concerning the response of the local landscape to past climatic fluctuations. In addition, variations in local landscape sensitivity related to prior erosional history and spatial variations in vegetation, and the localized nature of many storms, probably contribute to the complexity of the geomorphic record. Nevertheless, the work discussed in this paper suggests a strong relation between regional climatic changes and local geomorphic history, and provides a framework for considering relations between modern processes, the record of past landscape changes, and future erosion and deposition on the Plateau and in surrounding areas. 


\section{SETTING}

The Pajarito Plateau is an area of gently-sloping mesas separated by numerous narrow canyons that are up to $180 \mathrm{~m}$ in depth. The Plateau is bordered on the west by the Sierra de los Valles (the eastern Jemez Mountains), and on the east by White Rock Canyon of the Rio Grande (Fig. 1). The part of the Plateau discussed in this paper is mainly between 1900 and $2300 \mathrm{~m}$ in elevation, although some contributing drainage basins in the Sierra de los Valles extend to over $3100 \mathrm{~m}$. None of the drainage basins were glaciated. Vegetation is dominated by ponderosa pine forest to the west and piñon-juniper woodlands to the east (Allen, 1989). Modern climate is semiarid, with average annual precipitation that ranges from about $300 \mathrm{~mm}$ on the eastern Plateau to about $500 \mathrm{~mm}$ on the western Plateau (Bowen, 1990). Roughly $40 \%$ of the precipitation occurs during intense convective storms in July and August, and these storms have been responsible for the most extensive surface erosion (e.g., Wilcox, 1994; Wilcox et al., in press) and the highest flood peaks on record.

Bedrock immediately beneath the mesa tops consists of massive early Pleistocene ignimbrites of the Tshirege Member of the Bandelier Tuff (Griggs, 1964; Smith et al., 1970). The canyon walls are mainly cut into the Tshirege Member, but also expose early Pleistocene alluvium and pumice beds of the Cerro Toledo interval, early Pleistocene ignimbrites and pumice beds of the Otowi Member of the Bandelier Tuff, Plio-Pleistocene fanglomerates of the Puye Formation, Pliocene basaltic rocks of the Cerros del Rio volcanic field, and Miocene to Pliocene dacites of the Tschicoma Formation. In most of the canyons, channel incision is impeded by Cerros del Rio basalts (or, in part, Puye fanglomerates) to the east, imposing major local base level constraints such that the streams are not directly influenced by base level changes along the Rio Grande.

Surficial deposits vary substantially in thickness and characteristics across the Pajarito Plateau. Tuff on the mesa tops is typically overlain by $0-2 \mathrm{~m}$ of soils and sediments, although mesa-top deposits locally exceed 3-4 m in thickness. Canyon walls include extensive cliffs, particularly on south-facing exposures, and also extensive colluvial deposits that range from finetextured slopewash to bouldery rockfall deposits. Alluvium in the canyon bottoms is typically dominated by sand derived from weathering of the Bandelier Tuff, although streams heading in the 
Sierra de los Valles generally transport dacite gravels as bedload. The alluvium locally exceeds 10 $\mathrm{m}$ in thickness, although it thins to $<1 \mathrm{~m}$ to the east near knickpoints in resistant bedrock units. A key late Quaternary stratigraphic marker on much of the Pajarito Plateau is the El Cajete pumice, erupted from the Jemez Mountains about 50-60 ka (Toyoda et al., 1995; Reneau et al., 1996), which provides precise correlation of horizons in diverse geomorphic settings.

\section{MESA TOPS}

Exposures of soils and sedimentary deposits on several mesas reveal a complex record of both erosion and deposition. The most complete mesa-top record examined so far is on Pajarito Mesa (site 2 of Fig. 1), where exceptional exposures were provided by $1300 \mathrm{~m}$ of trenches (Kolbe et al., 1994, and unpubl. report for Los Alamos National Laboratory, 1994; Reneau et al., in press). The El Cajete pumice was present in most of the trenches, overlying a soil with a welldeveloped argillic Bt horizon (unit 3 of Fig. 2). The degree of soil development in this buried unit indicates on the order of perhaps $50-100 \mathrm{ky}$ of relative stability of the mesa top prior to $50-60 \mathrm{ka}$, based on a comparison with soils formed in late Pleistocene deposits at other locations on the Pajarito Plateau (McDonald et al., this volume). Similar or better developed pre-El Cajete soils are common (but not universal) on other Pajarito Plateau mesa tops (e.g., Longmire et al., in press).

Overlying the El Cajete pumice at Pajarito Mesa is a complex, in part discontinuous, sequence of units with radiocarbon ages extending back to $30 \mathrm{ka}$ (units 1 and 2 of Fig. 2; Kolbe et al., unpubl. report for Los Alamos National Laboratory, 1994; Reneau et al., in press). The abundance of silt in the upper units (about 55-65\% silt; P. Watt and E. McDonald, unpubl. 1995), deposited on top of the pumice bed, and the absence of an upslope source for fine sediment on this mesa, implies significant eolian contributions to the mesa-top soils (although such eolian sediment may be locally reworked). Shallow Paleo-Indian fire pits within and buried by fine-grained sediments at two locations, identified by the presence of oxidized tuff clasts and charcoal and dated at ca. $9.5{ }^{14} \mathrm{C} \mathrm{ka}$ (Fig. 2a), and an additional date of $9.4{ }^{14} \mathrm{C} \mathrm{ka}$ from a correlative fine-grained deposit, suggest an early Holocene period of mesa-top aggradation associated with high rates of eolian sediment influx. A more recent episode of enhanced eolian input is suggested by a fine- 
grained deposit (unit 1), averaging 10-30 cm thick, that occurs throughout the trenches and that buries several Anasazi sites with radiocarbon ages of about $760-1020$ yr B.P. $(\sim 1000-1300 \mathrm{cal}$ A.D.) (Fig. 2b). Similar fine-grained deposits that probably record late Quaternary eolian influx are widespread on the Plateau (e.g., Longmire et al., in press), although no other sites have yet yielded age control, and the timing and duration of eolian events on the Plateau are probably incompletely defined.

Considerable variability exists in the soils and stratigraphic units on individual mesas of the Pajarito Plateau, indicating significant spatial variations in the magnitude and extent of late Quaternary erosion. For example, a series of mesa-top trenches $600 \mathrm{~m}$ in total length excavated along Pajarito Road (site PR of Fig. 1; Kolbe et al., unpubl. report for Los Alamos National Laboratory, 1995), only $0.8 \mathrm{~km}$ north of the Pajarito Mesa trenches, displayed units that were much different than on Pajarito Mesa, including generally thinner soils and the virtual absence of El Cajete pumice. Total post-El Cajete erosion at the Pajarito Road trench sites has apparently been much greater than that on Pajarito Mesa. Although the reasons for these local variations in erosion are not certain, the mesa along Pajarito Road has a much broader crest than Pajarito Mesa, perhaps resulting in a greater concentration of surface runoff (due to less divergence of runoff onto mesa shoulders) and consequently greater erosion.

Additional records of the erosional history of Pajarito Plateau mesa tops are provided by deposits occurring within shallow mesa-top drainages. At one site east of the Los Alamos townsite ("EG\&G gully", Fig. 3), a 4-m section of Holocene fill is exposed in gully walls (Longmire et al., in press). Rapid deposition of the lower half of this section is indicated by two statistically indistinguishable radiocarbon dates of ca. $8 \mathrm{ka}$, separated by about $1 \mathrm{~m}$ of sediment (Fig. 3), presumably recording a period of accelerated erosion of the surrounding mesa-top soils. A period of subsequent stability or minimal aggradation after $8 \mathrm{ka}$ is indicated by a buried soil within the section, which was followed by renewed deposition beginning at or before $4.0{ }^{14} \mathrm{C} \mathrm{ka} \mathrm{(Fig.} \mathrm{3).}$ As discussed in later sections, this mesa-top record is consistent with the stratigraphic record in several canyons that also indicate major valley bottom aggradation during the early Holocene, 
providing evidence for a major change in erosional processes that coincided with the PleistoceneHolocene climatic transition.

Field observations indicate that modern surface erosion is much higher on the drier, eastern Plateau than to the west, and large areas are currently being eroded on the eastern Plateau, stripping both the El Cajete pumice and underlying soils and exposing Bandelier Tuff bedrock in many areas (e.g., site SR4 of Fig. 1, discussed in Longmire et al., in press). A small monitored watershed on the eastern Plateau near Frijoles Canyon (Frijolito watershed, Fig. 1) is presently eroding at the rapid rate of several $\mathrm{mm} / \mathrm{yr}$, a rate that would strip all the soil within centuries (Wilcox et al., in press). The modern erosion rates at the Frijolito watershed and elsewhere on the eastern Plateau may be heavily influenced by land use changes since 1880 , including the loss of ground cover due to grazing (Allen, 1989; Wilcox et al., in press), and the relation of the modern erosion to prehistoric periods of accelerated erosion is uncertain.

\section{CANYON WALLS}

Few chronologic data have been obtained from deposits along canyon walls on the Pajarito Plateau, although available data suggest erosion rates that are high enough so that the "residence times" of colluvium at many or most mid-slope sites are short. Radiocarbon data from two steep $\left(\sim 30^{\circ}\right)$ sites in Cañon de Valle, on both north- and south-facing slopes, indicate ages of $<1.0$ ka for mid-slope colluvium (Fig. 4), consistent with the weakly-developed soils present on these slopes (A-R or A-Bw-R profiles; E. McDonald and S. Reneau, unpubl. 1995). Buried soils within colluvial aprons below these mid-slope sites record episodic transport of colluvium off the slopes for the last $4{ }^{14} \mathrm{C}$ ka (Fig. 4). Similar young ages of $\leq 3{ }^{14} \mathrm{C}$ ka have been obtained from buried soils within a colluvial apron at the base of a steep north-facing slope in upper Los Alamos Canyon (Longmire et al., in press). Abundant evidence of active erosion on canyon walls during summer thunderstorms (such as debris lobes below shallow canyon-wall channels), particularly on southfacing slopes, suggests that these slopes contribute a significant (though not quantified) amount of sediment to the stream channels. 
Dissected remnants of older, Pleistocene colluvial deposits, both pre-dating and post-dating the El Cajete pumice, are widespread along the lower slopes in many canyons, preserving an older record of hillslope processes and suggesting episodic deposition and erosion of colluvium through the late Quatemary. One such lower-slope colluvial deposit in DP Canyon, overlying stream sediments dated at ca. $26.7{ }^{14} \mathrm{C} \mathrm{ka}$, has yielded an age of $21.6{ }^{14} \mathrm{C} \mathrm{ka}$ (Reneau, 1995), and the upper parts of two toe-slope deposits along the north fork of Ancho Canyon yielded ages of 16.6 and $20.6{ }^{14} \mathrm{C} \mathrm{ka}$ (S. Reneau, unpubl. 1994). Both of these dated Ancho Canyon deposits overlie the El Cajete pumice, and stratigraphic relations, the apparent absence of buried soils, and additional ${ }^{14} \mathrm{C}$ dates ( 32.8 and $44.4 \mathrm{ka}$ ) suggest that deposition of colluvium began at or before 50$60 \mathrm{ka}$ and continued without major breaks until 17-21 ka, with minimal aggradation or net erosion occurring at these sites since then.

\section{CANYON BOTTOMS}

Canyon bottoms on the Pajarito Plateau show considerable diversity in their record of late Quaternary erosion and deposition, with some experiencing net aggradation while others experienced net incision, although all that have been studied indicate major geomorphic changes through the late Pleistocene and the Holocene.

At one extreme are canyons that have significantly incised into tuff, producing terraces that record temporary pauses in this incision or local aggradation. Both strath terraces, recording lateral stream erosion and concurrent development of floodplains, and fill terraces, recording significant channel aggradation, are present, although the distinction between strath and fill terraces is often not clear. In part of Frijoles Canyon, terrace remnants dated at ca. $5.3-6.2{ }^{14} \mathrm{C}$ ka are stranded up to $25 \mathrm{~m}$ above the modern channel (Fig. 5; Reneau et al., 1993), indicating average incision rates of up to $4 \mathrm{~mm} / \mathrm{yr}$ since the mid Holocene. Along Rendija Canyon (Fig. 1), terraces dated at ca. 8.8-8.9 ${ }^{14} \mathrm{C}$ ka. occur $7 \mathrm{~m}$ above the modern channel, and a well-dated sequence of lower terraces document progressive incision during the Holocene at rates of $\sim 1 \mathrm{~mm} / \mathrm{yr}$ (see Gardner and Reneau, this volume, and McDonald et al., this volume). 
In contrast to the record of incision present in some canyons, extensive late Quaternary aggradation is recorded in many others. A 4-m deep trench excavated in Cabra Canyon (Fig. 1), only $0.6 \mathrm{~km}$ from an incising part of Rendija Canyon, exposed deposits that document net aggradation since at least $4 .{ }^{14} \mathrm{C} \mathrm{ka}$, interrupted by several channel cutting events (Gardner and Reneau, this volume). A borehole in Los Alamos Canyon (LADP-3) penetrated the ca. 50-60 ka El Cajete pumice (largely or entirely reworked) as deep as $\sim 7 \mathrm{~m}$ below the modern channel (Broxton et al., 1995), thus demonstrating net aggradation since that time. Sediment samples from core holes in both Ancho and Mortandad Canyons indicate the presence of a complex stratigraphy buried beneath the canyon floor, including pure layers of El Cajete pumice that, at least in part, represent primary fallout deposits (Fig. 6). The El Cajete pumice may have been deposited either on broad, generally unincised canyon bottoms, as are present today in these canyons, or on terraces, and was subsequently buried during a period of extensive aggradation. The magnitude of Holocene aggradation is indicated by radiocarbon dates on charcoal fragments from core holes in Ancho and Mortandad Canyons. A floodplain deposit $4 \mathrm{~m}$ below the modern channel along the north fork of Ancho Canyon yielded a date of $9.9{ }^{14} \mathrm{C} \mathrm{ka}$, and coarse channel sands $10-12 \mathrm{~m}$ deep in Mortandad Canyon yielded dates of $7.2-7.8{ }^{14} \mathrm{C}$ ka (Fig. 6). These data indicate average Holocene aggradation rates of $0.5->1.5 \mathrm{~mm} / \mathrm{yr}$ in some canyons, although we expect that rates of sediment deposition have been highly variable; for example, part of Frijoles Canyon had aggraded at least $13 \mathrm{~m}$ before $6.2{ }^{14} \mathrm{C} \mathrm{ka}$, while subsequently experiencing net incision since $6.2 \mathrm{ka}$ (Reneau et al., 1993).

Available data from Pajarito Plateau canyons suggest that a major change in fluvial systems occurred at or near the Pleistocene-Holocene climatic transition. The highest of the late-Quaternary flight of terraces in part of Frijoles Canyon yielded an age of $8.2{ }^{14} \mathrm{C}$ ka (S. Reneau, unpubl. 1994), and a prominent Rendija Canyon terrace has yielded ages of $8.8-8.9{ }^{14} \mathrm{C}$ ka. Notably, soil characteristics suggest that the next higher Rendija Canyon terrace is $>50 \mathrm{ka}$ in age (McDonald et al., this volume), and the apparent absence of terraces between about 10 and 20 ka provides supporting evidence that the latest Pleistocene fluvial systems on the Pajarito Plateau were significantly different from the Holocene streams. Along the north fork of Ancho Canyon, channel 
aggradation near the upstream end of the modern valley floor had commenced by at least $8.8{ }^{14} \mathrm{C}$ ka (S. Reneau, unpubl. 1994), and subsurface data (Fig. 6A) suggest that aggradation downstream may have begun by $11.6^{14} \mathrm{C}$ ka. Data from a $4-\mathrm{m}$ thick section exposed at the east end of Mesita del Buey, at the head of a minor tributary to Cañada del Buey, indicates inception of aggradation close to $10^{14} \mathrm{C} \mathrm{ka}$, with episodic deposition during the Holocene suggested by the apparent presence of buried soils in the section (Fig. 7). These records are similar to that at "EG\&G gully" (Fig. 3), where aggradation in a shallow mesa-top drainage commenced around $8.0{ }^{14} \mathrm{C} \mathrm{ka}$.

Stratigraphic relations and radiocarbon dating indicate that the mid to late Holocene sediments in many canyons record repeated episodes of alternating channel aggradation or stability and channel incision (e.g., Cabra Canyon; Gardner and Reneau, this volume), as has also been observed in drainages throughout the Southwest (e.g., Miller and Wendorf, 1958; Hall, 1977; Love, 1983; Karlstrom, 1988; Balling and Wells, 1990). However, the available data are not sufficient to determine if such episodes were large y synchronous across the Pajarito Plateau (which would imply a control imposed by regional climatic variations), or if they instead vary significantly in timing between canyons.

Changes between aggradation and incision have continued into historic time along both low order and high order channels, although, in detail, the canyons are not displaying synchronous behavior in regard to the timing of recent geomorphic changes. For example, an examination of sequential airphotos showed that a presently unchanneled, aggrading part of Potrillo Canyon possessed a channel until at least 1965 (Becker, 1991). In contrast, exposures along DP and Pueblo Canyons show that since major development began at the Los Alamos townsite (ca. 1943 A.D.), up to 2-3 m of sediment were first deposited and then incised (Reneau, 1995; Graf, in press). Drakos and Inoue (unpubl. reports for Los Alamos National Laboratory, 1993, 1994) and Aldrich and Harrington (1995) also report observations of historic cut-and-fill along Bayo and Los Alamos Canyons, and along a small drainage near the Los Alamos townsite. It is not known to what extent land use changes have affected the historic erosion and deposition along Pajarito Plateau channels, although we suspect that, at least locally, increases in sediment supply 
accompanying development has resulted in aggradation, and that increases in the extent of impermeable surfaces has increased flood peaks, resulting in incision.

\section{EFFECTS OF REGIONAL CLIMATIC CHANGES}

Many studies have demonstrated that major changes in both vegetation and the amount and seasonal distribution of precipitation accompanied climatic changes at the Pleistocene-Holocene transition across the American Southwest, as discussed below. These late Quaternary changes in climate likely resulted in significant changes in geomorphic processes on the Pajarito Plateau, although the sensitivity of the land surface to climatic change probably varied greatly across the landscape related to factors such as local vegetation, catchment area, and slope gradient.

Available paleoclimatic data indicate that the late Pleistocene climate of the Southwest was wetter than today, with precipitation probably dominated by winter frontal storms (shown schematically in Fig. 8A) (Spaulding et al., 1983; Hall, 1985; Van Devender et al., 1987; Allen, 1991; Phillips et al., 1992; Thompson et al., 1993). Late Pleistocene vegetation at the elevation of the Pajarito Plateau elsewhere in the Southwest included montane forests or parklands of spruce and fir (Wright et al., 1973; Betancourt, 1990; Anderson, 1993). Vegetation more closely resembling modern communities became established perhaps around $10{ }^{14} \mathrm{C} \mathrm{ka}$, associated with a warmer, drier climate than in the latest Pleistocene and greatly enhanced summer precipitation. A variety of paleoclimate records from the Rocky Mountains of Colorado, the Colorado Plateau, and the southwestern deserts imply that summer rainfall in the early Holocene was higher than today (Fig. 8A), indicating stronger monsoonal circulation at that time (e.g., Markgraf and Scott, 1981; Friedman et al., 1988; Betancourt, 1990; Davis and Shafer, 1992; Thompson et al., 1993).

The apparent concurrence of these changes in vegetation and storm characteristics with the inception of major aggradation or episodic terrace formation on the Pajarito Plateau (shown schematically in Fig. 8B), suggest that these climatic changes triggered a period of accelerated erosion and increased sediment supply within the drainage basins of the Plateau. Although there are relatively few published records elsewhere in the region pertaining to possible changes in fluvial systems at this time, other workers from diverse areas have reported the inception of 
widespread aggradation near the Pleistocene-Holocene transition (e.g., Holliday and Gustavson, 1991; Wells, 1994), providing some support for the regional nature of significant changes in geomorphic processes associated with late Quaternary climatic changes.

Major episodes of aggradation at the Pleistocene-Holocene transition elsewhere in the Southwest have been attributed primarily to destabilization of slopes caused by major reductions in vegetation, such as from woodlands to desert scrub communities (e.g., Bull, 1991). However, field observations suggest that much of the cobble- to boulder-sized gravel associated with aggradation along many Pajarito Plateau streams was derived from north-facing slopes and the higher elevation, western parts of drainage basins that remained forested into the Holocene. For example, bouldery Holocene debris fans are common below steep north-facing slopes in Frijoles Canyon, and coarse gravelly late Quaternary fans occur along many streams on the western Plateau where they exit the Sierra de los Valles. Although the age of these fans is not well constrained at present, soils developed in the Cañon de Valle fan suggest an early Holocene age (E. McDonald, unpubl. 1995). The coarse texture of these deposits suggest original mobilization of the sediment from hillslopes as debris flows, which are typically triggered during high intensity storms (e.g., Neary and Swift, 1987; Wieczorek, 1987). Recent observations of a debris flow on a north-facing slope in the Frijoles Canyon watershed, triggered by a summer thunderstorm (S. Reneau, unpubl. 1991), demonstrate that this is an active process under modern climate, although the relative importance of debris flows in providing coarse sediment to Pajarito Plateau channels is not quantified. Based on these observations, we infer that the enhancement of intense summer rainfall in the early Holocene may have been significant in accelerating erosion and increasing the supply of sediment in local watersheds, and that, at least on the forested slopes, the effects of vegetation changes may have been of lesser importance.

The accelerated erosion of mesa-top soils in the early Holocene requires a different process than that occurring on forested slopes, and mesa-top erosion has probably been dominated by surface runoff. Under modern climate, this erosion is greatest during intense summer thunderstorms, and is most effective on bare ground in "intercanopy" areas (Wilcox, 1994; Wilcox et al., in press). These relations suggest that changes in ground cover may have been critical in 
controlling long-term variations in mesa-top erosion, although temporal variability in ground cover cannot be estimated at present. The local abundance of charcoal in some deposits (e.g., "EG\&G gully", Fig. 3) suggests that erosion following fires (cf. White and Wells, 1984) may also have contributed to some of the mesa-top erosion, although the importance of fires in influencing Holocene erosion rates is unknown.

An additional geomorphic response to late Quaternary climatic change, as indicated by the stratigraphic record at Pajarito Mesa (Fig. 2), may have been a significant increase in the rate of eolian deposition on the Pajarito Plateau, including the period $9.4-9.5{ }^{14} \mathrm{C} \mathrm{ka} \mathrm{(Fig.} \mathrm{8B).} \mathrm{This}$ eolian sediment may have partly had a source along aggrading stream channels, either within Pajarito Plateau canyons or farther to the south, and an increase in eolian sediment transport could thus been a secondary effect of an early Holocene increase in fluvial sediment transport. However, the eolian record on the Pajarito Plateau is poorly understood, with only Pajarito Mesa yielding age control, and determining the timing and duration of eolian events, and the actual source for the sediment, will require additional work.

Late Pleistocene geomorphic processes on the Pajarito Plateau are poorly understood due to the scarcity of deposits dated to between 10 and $20 \mathrm{ka}$. The apparent rarity of stream deposits from this period suggests that minimal aggradation occurred within the canyons, and it is possible that many streams had incised to bedrock along presently alluvial reaches. An absence of major late Pleistocene stream deposits suggests lower basin-wide erosion rates associated with lesser amounts of summer rainfall, and possibly higher sediment transport capacity associated with snowmelt floods that were larger and of longer duration than today. Kelson and Wells (1987) used similar reasoning to explain why a largely nonglaciated basin near Taos apparently experienced incision during glacial periods and floodplain formation during interglacial periods. In contrast to the inferred low erosion rates on the Pajarito Plateau in the latest Pleistocene, available data indicate that adjacent areas in White Rock Canyon experienced an enhancement of large-scale landsliding at that time (Fig. 8; see Reneau and Dethier, this volume), illustrating how local variations in landscape sensitivity may result in much different responses to the same climate changes. 
The role of Holocene climatic fluctuations in producing the alternation of channel cutting and filling seen in some Pajarito Plateau canyons (i.e., Cabra Canyon), or the alternation of lateral cutting and incision into bedrock seen in others (i.e., Frijoles and Rendija Canyons), is not clear. The available data have not yet revealed mid to late Holocene geomorphic events that are synchronous across the Plateau, although the data set is still relatively small. Although workers elsewhere in the Southwest have proposed that Holocene erosional and depositional episodes along streams display strong synchroneity and are controlled by regional climatic fluctuations (e.g., Karlstrom, 1988), other processes involving complex responses along the channels related to internal drainage basin parameters (Schumm, 1977; Bull, 1991) or rare high-magnitude storms may also contribute to the record of erosion and deposition within Pajarito Plateau canyons. In addition, we expect that progressive reductions in sediment yield and progressive increases in surface runoff during the Holocene may have resulted from the stripping of soils and consequent increase in exposure of tuff bedrock, which could have locally caused incision of early to mid Holocene fills without changes in storm characteristics; such process-response models have been proposed for other arid or semiarid areas (Bull, 1991).

\section{CONCLUSIONS}

Sediments and soils on the Pajarito Plateau contain a diverse record of late Quaternary erosion and deposition that is probably strongly affected by regional climatic changes. Available data indicate that at least some of the streams were incised below their present level in the late Pleistocene and have subsequently aggraded in the Holocene, and this aggradation was probably due to $\perp$ major increase in basin-wide erosion rates and sediment supply accompanying the Pleistocene-Holocene transition. Although the processes producing such accelerated erosion are not certain, they may have been aided by an enhancement of intense summer rainfall in the early Holocene. Erosion has continued into modern times, progressively stripping soils from mesa tops, including well-developed soils that are older than $50-60 \mathrm{ka}$, and exposing tuff bedrock in many areas. Additional effects of climatic change near the Pleistocene-Holocene transition 
probably include an increased influx of eolian sediment onto mesas, accounting for local mesa-top aggradation despite the high erosion rates that have apparently characterized the Holocene.

The canyons of the Pajarito Plateau show considerable variability in their behavior in the Holocene, with some experiencing progressive incision into tuff that was interrupted by periods of lateral cutting and floodplain development, while others experienced progressive aggradation that was interrupted by episodes of channel cutting into the alluvial fills. We believe that variations in drainage area, channel gradient, and bed material size between canyons probably contribute to the varied late Quaternary geomorphic history seen on the Pajarito Plateau, although these variables have not yet been examined in detail. The effects of regional climatic changes during the Holocene on erosion and deposition on the Plateau are also not certain, and available data have not yet revealed mid to late Holocene changes in geomorphic processes that are synchronous across the Plateau. Determining the relative importance of regional climatic changes in comparison with more local controls on Holocene episodes of erosion and deposition on the Pajarito Plateau thus requires further work.

\section{ACKNOWLEDGMENTS}

This work was funded by the U.S. Department of Energy through the Los Alamos National Laboratory Environmental Restoration Project and Seismic Hazard Investigations Program. The authors thank Bandelier National Monument for permission to collect samples in Frijoles Canyon; Ken Shisler and Steve McLin for copies of unpublished core logs and for core samples from Ancho and Mortandad Canyons; Kirk Anderson, Antonio Garcia, and Penny Gomez for field assistance; Craig Allen, Kirk Anderson, Paul Drakos, Steve Forman, Will Graf, Chuck Harrington, Steve Hoagland, Keith Kelson, Bev Larson, Les McFadden, Susan Olig, Dave Simpson, and Brad Wilcox for many discussions concerning the late Quaternary record on the Pajarito Plateau; and David Dethier, Steve Hall, Chuck Harrington, Les McFadden, and Brad Wilcox for helpful review comments. 
Reneau et al. p. 15

\section{REFERENCES}

Aldrich, M. J., Jr., and Harrington, C. D., 1995, Importance of understanding surface processes at environmental cleanup sites in obtaining representative samples: Geological Society of America, Abstracts with Programs, v. 27, no. 6, p. A-88.

Allen, C. D., 1989, Changes in the landscape of the Jemez Mountains, New Mexico [Ph.D. thesis]: Berkeley, University of California, 346 p.

Allen, B. D., 1991, Effect of climatic change on Estancia Valley, New Mexico: Sedimentation and landscape evolution in a closed-drainage basin: New Mexico Bureau of Mines and Mineral Resources, Bulletin 137, p. 166-171.

Anderson, R. S., 1993, A 35,000 year vegetation and climate history from Potato Lake, Mogollon Rim, Arizona: Quaternary Research, v. 40, p. 351-359.

Balling, R. C., Jr., and Wells, S. G., 1990, Historical rainfall patterns and arroyo activity within the Zuni River drainage basin, New Mexico: Annals of the Association of American Geographers, v. 80, p. 603-617.

Becker, N. M., 1991, Influence of hydraulic and geomorphologic components of a semi-arid watershed on depleted uranium transport [Ph.D. thesis]: Madison, University of Wisconsin, $237 \mathrm{p}$.

Betancourt, J. L., 1990, Late Quaternary biogeography of the Colorado Plateau; in Betancourt, J. L., Van Devender, T. R., and Martin, P. S., eds., Packrat middens--The last 40,000 years of biotic change: Tucson, University of Arizona Press, p. 259-292.

Bowen, B. M., 1990, Los Alamos climatology: Los Alamos National Laboratory Report LA11735-MS, 254 p.

Broxton, D. E., Longmire, P. A., Eller, P. G., and Flores, D., 1995, Preliminary drilling results for boreholes LADP-3 and LADP-4; in Broxton, D. E., and Eller, P. G., eds., Earth science investigations for environmental restoration--Los Alamos National Laboratory Technical Area 21: Los Alamos National Laboratory Report LA-12934-MS, p. 93-109.

Bull, W. B., 1991, Geomorphic responses to climatic change: New York, Oxford University Press, $326 \mathrm{p}$. 
Davis, O. K., and Shafer, D. S., 1992, A Holocene climatic record for the Sonoran Desert from pollen analysis of Montezuma Well, Arizona, USA: Palaeogeography, Palaeoclimatology, Palaeoecology, v. 92, p. 107-119.

Friedman, L., Carrara, P., and Gleason, J., 1988, Isotopic evidence of Holocene climatic change in the San Juan Mountains, Colorado: Quaternary Research, v. 30, p. 350-353.

Gardner, J. N., and Reneau, S. L., Holocene faulting and sedimentation within the Guaje Mountain fault zone: this volume.

Graf, W. L., in press, Transport and deposition of plutonium contaminated sediments, Los Alamos Canyon, New Mexico: Geological Society of America Bulletin.

Griggs, R. L., 1964, Geology and groundwater resources of the Los Alamos area, New Mexico: U.S. Geological Survey Water-Supply Paper 1735, 107 p.

Hall, S. A., 1977, Late Quatemary sedimentation and paleoecologic history of Chaco Canyon, New Mexico: Geological Society of America Bulletin, v. 88, p. 1593-1618.

Hall, S. A., 1985, Quaternary pollen analysis and vegetational history of the Southwest; in Bryant, V. M., Jr., and Holloway, R. G., eds., Pollen records of late-Quaternary North American Sediments: Dallas, American Assaciation of Stratigraphic Palynologists, p. 95-123.

Holliday, V. T., and Gustavson, T. C., 1991, Quaternary stratigraphy and soils of the Southern High Plains; in Morrison, R. B., ed., Quaternary nonglacial geology: Conterminous U.S.: Boulder, Geological Society of America, The Geology of North America, v. K-2, p. 479-484.

Karlstrom, T. N. V., 1988, Alluvial chronology and hydrologic change of Black Mesa and nearby regions; in Gumerman, G. J., ed., The Anasazi in a changing environment: Cambridge, Cambridge University Press, p. 45-91.

Kelson, K. I., and Wells, S. G., 1987, Present-day fluvial hydrology and long-term tributary adjustments, northern New Mexico; in Menges, C., ed., Quaternary tectonics, landform evolution, soil chronologies and glacial deposits--northern Rio Grande rift of New Mexico: Friends of the Pleistocene-Rocky Mountain Cell Field Trip Guidebook, p. 95-109.

Kolbe, T. R., Simpson, D. T., Loskutoff, W., Gorton, A. E., Reneau, S. L., and Carney, J. S., 1994 , Use of soil stratigraphy and fracture analyses to evaluate possible faulting on Pajarito 
Mesa, Los Alamos National Laboratory, northern New Mexico: Geological Society of America, Abstracts with Programs, v. 26, no. 6, p. 24.

Longmire, P., Reneau, S., Watt, P., McFadden, L., Gardner, J., Duffy, C., and Ryti, R., in press, Natural background geochemistry, geomorphology, and pedogenesis of selected soil profiles and Bandelier Tuff, Los Alamos, New Mexico, 1995: Los Alamos National Laboratory Report LA-12913-MS.

Love, D. W., 1983, Summary of the late Cenozoic geomorphic and depositional history of Chaco Canyon; in Wells, S. G., Love, D. W., and Gardner, T. W., eds., Chaco Canyon country: American Geomorphological Field Group 1983 Field Trip Guidebook, p. 187-194.

Markgraf, V., and Scott, L., 1981, Lower timberline in central Colorado during the past 15,000 yr: Geology, v. 9, p. 231-234.

McDonald, E. V., Reneau, S. L., and Gardner, J. N., Soil-forming processes on the Pajarito Plateau: Investigation of a soil chronosequence in Rendija Canyon: this volume.

Miller, J. P., and Wendorf, F., 1958, Alluvial chronology of the Tesuque Valley, New Mexico: Journal of Geology, v. 66, p. 177-194.

Neary, D. G., and Swift, L. W., Jr., 1987, Rainfall thresholds for triggering a debris avalanching event in the southern Appalachian Mountains; in Costa, J. E., and Wieczorek, G. F., eds., Debris flows/avalanches: Process, recognition, and mitigation: Geological Society of America Reviews in Engineering Geology, v. 7, p. 81-92.

Phillips, F. M., Campbell, A. R., Kruger, C., Johnson, P., Roberts, R., and Keyes, E., 1992, A reconstruction of the response of the water balance in western United States lake basins to climatic change: New Mexico Water Resources Research Institute Report No. 269, v. 1, 167 p.

Reneau, S. L., 1995, Geomorphic studies at DP Mesa and vicinity; in Broxton, D. E., and Eller, P. G., eds., Earth science investigations for environmental restoration--Los Alamos National Laboratory Technical Area 21: Los Alamos National Laboratory Report LA-12934-MS, p. 6592. 
Reneau, S. L., and Dethier, D. P., Pliocene and Quaternary history of the Rio Grande, White Rock Canyon and vicinity, New Mexico: this volume.

Reneau, S. L., Gardner, J. N., Kelson, K. I., and Hemphill-Haley, M. A., 1993, Holocene stream aggradation and degradation, Pajarito Plateau, northern New Mexico: Geological Society of America, Abstracts with Programs, v. 25, no. 5, p. 138.

Reneau, S. L., Gardner, J. N., and Forman, S. L., 1996, New evidence for the age of the youngest eruptions in the Valles caldera, New Mexico: Geology, v. 24, p. 7-10.

Reneau, S. L., Kolbe, T., Simpson, D., Carney, J. S., Gardner, J. N., Olig, S. S., and Vaniman, D. T., in press, Surficial materials and structure at Pajarito Mesa; in Reneau, S. L., and Raymond, R., Jr., eds., Geological site characterization for the proposed Mixed Waste Disposal Facility, Los Alamos National Laboratory: Los Alamos National Laboratory Report LA-13089-MS.

Schumm, S. A., 1977, The fluvial system: New York, John Wiley \& Sons, 338 p.

Smith, R. L., Bailey, R. A., and Ross, C. S., 1970, Geologic map of the Jemez Mountains, New Mexico: U.S. Geological Survey Miscellaneous Geologic Investigations Map I-571, scale $1: 125,000$.

Spaulding, W. G., Leopold, E. B., and Van Devender, T. R., 1983, Late Wisconsin paleoecology of the American Southwest; in Porter, S. C., ed., Late-Quaternary environments of the United States, Vol. I, The late Pleistocene, p. 259-293.

Thompson, R. S., Whitlock, C., Bartlein, P. J., Harrison, S. P., and Spaulding, W. G., 1993, Climatic changes in the western United States since 18,000 yr B.P.; in Wright, H. E., Jr., Kutzbach, J. E., Webb, T., III, Ruddiman, W. F., Street-Perrott, F. A. and Bartlein, P. J., eds., Global climates since the last glacial maximum: Minneapolis, University of Minnesota Press, p. 468-513.

Toyoda, S., Goff, F., Ikeda, S., and Ikeya, M., 1995, ESR dating of quartz phenocrysts in the El Cajete and Battleship Rock Members of Valles Rhyolite, Valles caldera, New Mexico: Journal of Volcanology and Geothermal Research, v. 67, p. 29-40. 
Van Devender, T. R., Thompson, R. S., and Betancourt, J. L., 1987, Vegetation history of the deserts of southwestern North America; The nature and timing of the Late Wisconsin-Holocene transition; in Ruddiman, W. F., and Wright, H. E., Jr., eds., North America and adjacent oceans during the last deglaciation: Boulder, Geological Society of America, The Geology of North America, v. K-3, p. 323-352.

Wells, S. G., 1994, Factors influencing arroyo dynamics, valley floor alluvial sequences, and drainage network evolution in the southeastern Colorado Plateau during the Holocene: EOS, v. 75 , p. 269.

White, W. D., and Wells, S. G., 1984, Geomorphic effects of La Mesa fire; in Foxx, T. S., compiler, La Mesa fire symposium: Los Alamos National Laboratory Report LA-9236-NERP, p. 73-90.

Wieczorek, G. F., 1987, Effect of rainfall intensity and duration on debris flows in central Santa Cruz Mountains, California; in Costa, J. E., and Wieczorek, G. F., eds., Debris flows/avalanches: Process, recognition, and mitigation: Geological Society of America Reviews in Engineering Geology, v. 7, p. 93-104.

Wilcox, B. P., 1994, Runoff and erosion in intercanopy zones of pinyon-juniper woodlands: Journal of Range Management, v. 47, p. 285-295.

Wilcox, B. P., Pitlick, J., Allen, C. D., and Davenport, D. W., in press, Runoff and erosion from a rapidly eroding pinyon-juniper hillslope; in Anderson, M., and Brooks, S., eds., Advances in hillslope processes: Chichester, John Wiley \& Sons.

Wright, H. E., Jr., Brent, A. M., Hansen, B. S., and Mahler, L. J., Jr., 1973, Present and past vegetation of the Chuska Mountains, northwestern New Mexico: Geological Society of America Bulletin, v. 84, p. 1155-1180. 


\section{FIGURE CAPTIONS}

FIGURE 1. Map showing selected drainages on the Pajarito Plateau and location of sites discussed in text. Filled circles indicate sites with radiocarbon age control mentioned in this paper, and open circles indicate other sites mentioned in text. Numbers indicate sites of Figures 2-7. DPC: DP Canyon; FW: Frijolito watershed; LA: Los Alamos; PM: Pajarito Mesa; PR: Pajarito Road trench sites; SR4: State Road 4 site.

FIGURE 2. Soil-stratigraphic units in Pajarito Mesa trenches and buried archaeological sites. (A) Log of part of trench E1, showing Paleo-Indian fire pit ( 2530 cal B.C.) in fine-grained early Holocene eolian (?) deposit. (B) Log of part of trench E8, showing Anasazi site ( 1280 cal A.D.) excavated into late Pleistocene and Holocene units, and buried by fine-grained late Holocene (eolian?) deposits (unit 1b, with typical ages of $540-710{ }^{14} \mathrm{C}$ yr B.P.; $1290-1410$ cal A.D.). A distinctive buried soil (unit 3) underlies the ca. 50-60 $\mathrm{ka}$ El Cajete pumice and is present throughout the trenches; unit $2 \mathrm{~b}$ is bioturbated El Cajete pumice, and unit $2 \mathrm{a}$ includes soils and deposits above the pumice which have yielded ages of $2-30^{14} \mathrm{C}$ ka. Horizontal axis indicates trench distance. No vertical exaggeration. (From Kolbe et al., unpubl. report for Los Alamos National Laboratory, 1994, and Reneau et al., in press.)

FIGURE 3. Cross section showing stratigraphy and radiocarbon dates at "EG\&G gully" (informal name), in a shallow mesa-top drainage east of the Los Alamos townsite (from Longmire et al., in press). The deposit is generally an unstratified loam or silt loam, except for sand and granule layers that occur in the ca. $8 \mathrm{ka}$ unit and which may record relatively high energy surface runoff.

FIGURE 4. Schematic cross section across Cañon de Valle (stream elevation $\sim 2240 \mathrm{~m}$ ), showing relations of colluvial soils on canyon walls, colluvial aprons at slope base, and Holocene alluvial fill. Canyon is about $70 \mathrm{~m}$ deep and $190 \mathrm{~m}$ wide here. (Thicknesses of surficial units are not to scale). 
FIGURE 5. Schematic cross section across bottom of Frijoles Canyon about $8 \mathrm{~km}$ upstream of the Rio Grande (stream elevation $\sim 1945 \mathrm{~m}$ ) showing mid Holocene terrace remnant and location of ${ }^{14} \mathrm{C}$ date in basal part of overlying colluvium. Stream-cut alcoves are formed in this canyon during periods of local base level stability and floodplain development (including about $5.3{ }^{14} \mathrm{C} \mathrm{ka}$ and today), and become stranded on cliff walls following renewed incision, recording former stream levels.

FIGURE 6. Cross sections across (A) north fork of Ancho Canyon and (B) Mortandad Canyon, showing radiocarbon dates and inferred stratigraphic context of units exposed in core holes. Stratigraphy modified from unpublished core logs (K. Shisler et al., unpubl. 1994; S. McLin et al., unpubl. 1994). Bedrock in (A) includes the Tshirege and Otowi Members of the Bandelier Tuff and alluvium of the intervening Cerro Toledo interval.

FIGURE 7. Sketch showing stratigraphy and radiocarbon dates at the head of a minor tributary to Cañada del Buey, at the east end of Mesita del Buey. This early to mid Holocene fill has been extensively dissected and eroded, and the modern channel is close to tuff bedrock.

FIGURE 8. Schematic representations of possible gross variations in (A) precipitation and (B) geomorphic processes on the Pajarito Plateau and in surrounding areas for the last 20,000 years, illustrating inferred temporal relations between climatic changes and the geomorphic record. Geomorphic processes presented here include: the supply of sediment to channels derived from erosion throughout the basins, and associated aggradation of channels; local mesa-top aggradation that probably records increased eolian influx; and large-scale landsliding. Vertical scales are intended to show relative differences between the late Pleistocene and the Holocene, as inferred from regional paleoclimatic records and from local geomorphic evidence, and not absolute values. Because available records are incomplete, the plotted curves are of necessity partly speculative. See text for discussion. 


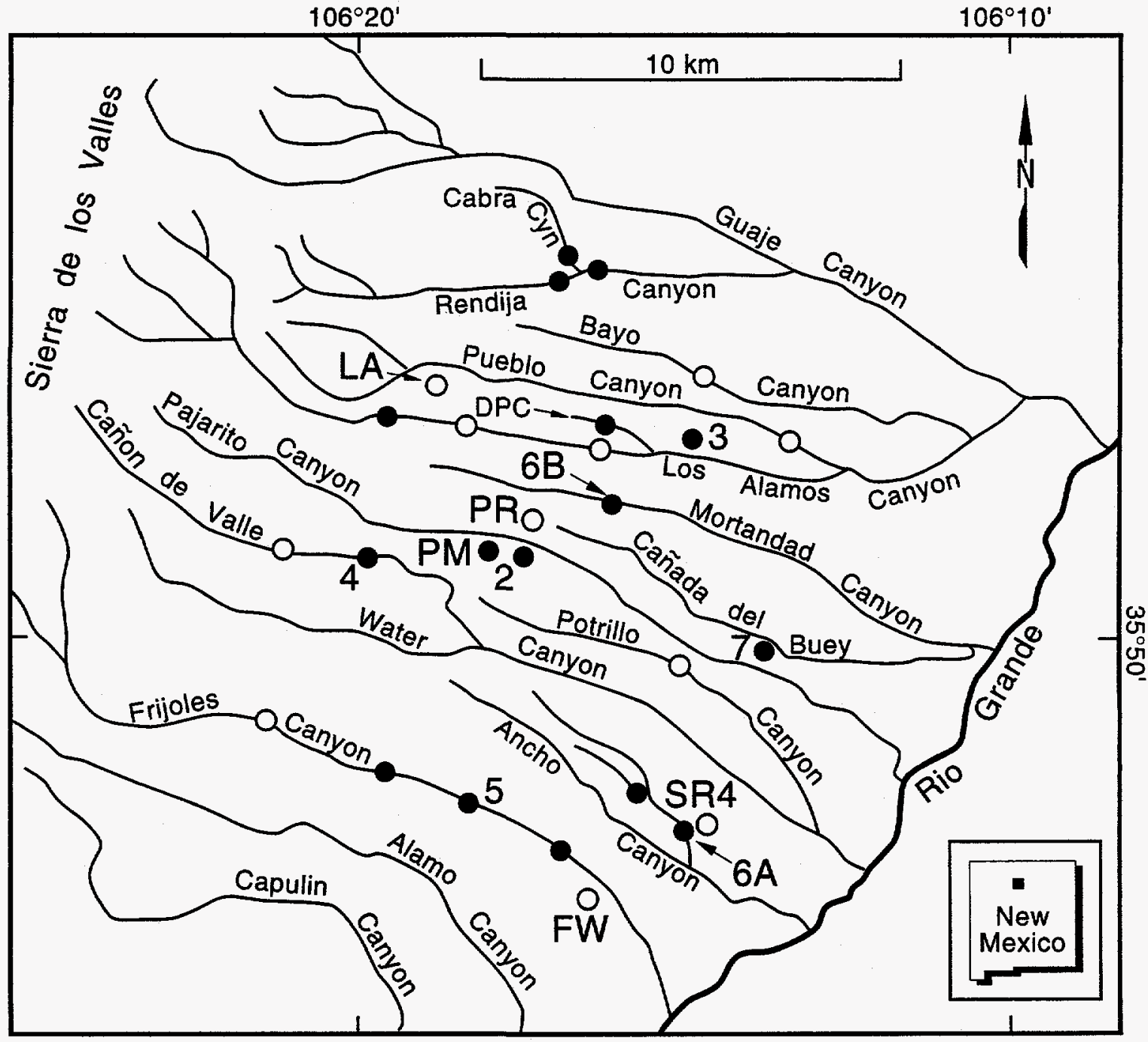

Fig. 1 
A

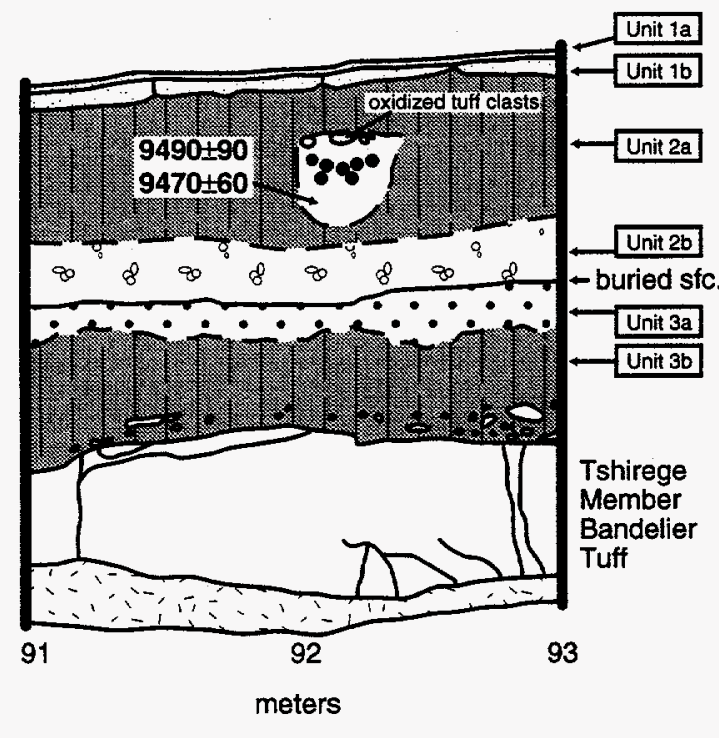

B

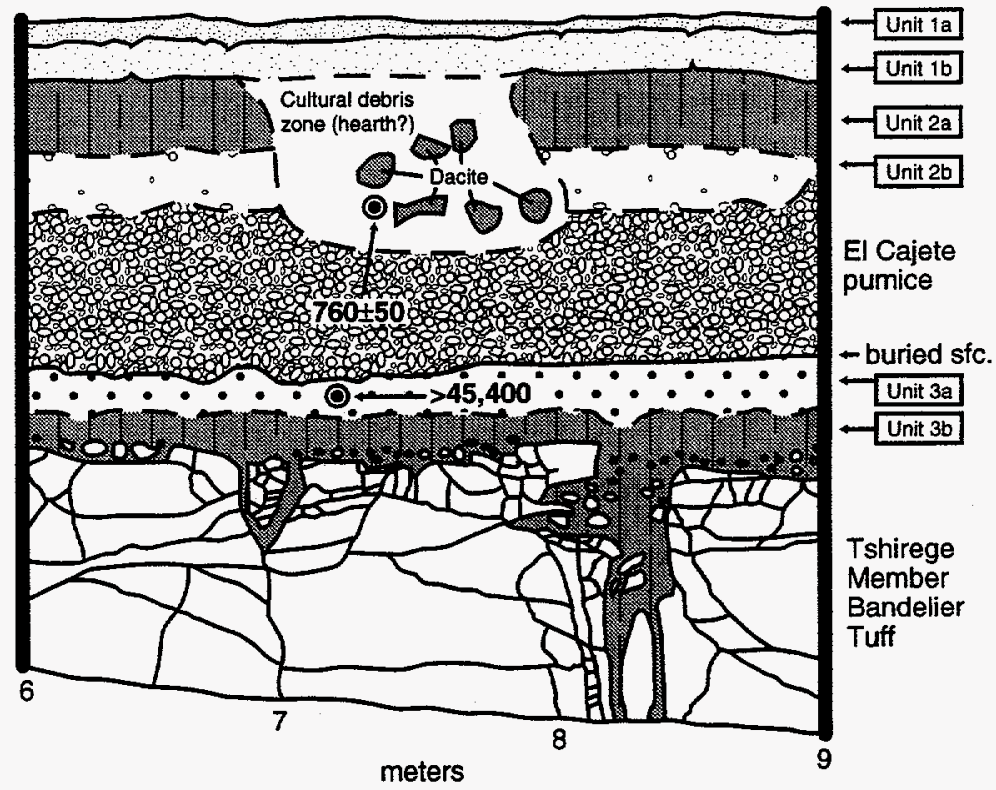

Fig. 2 


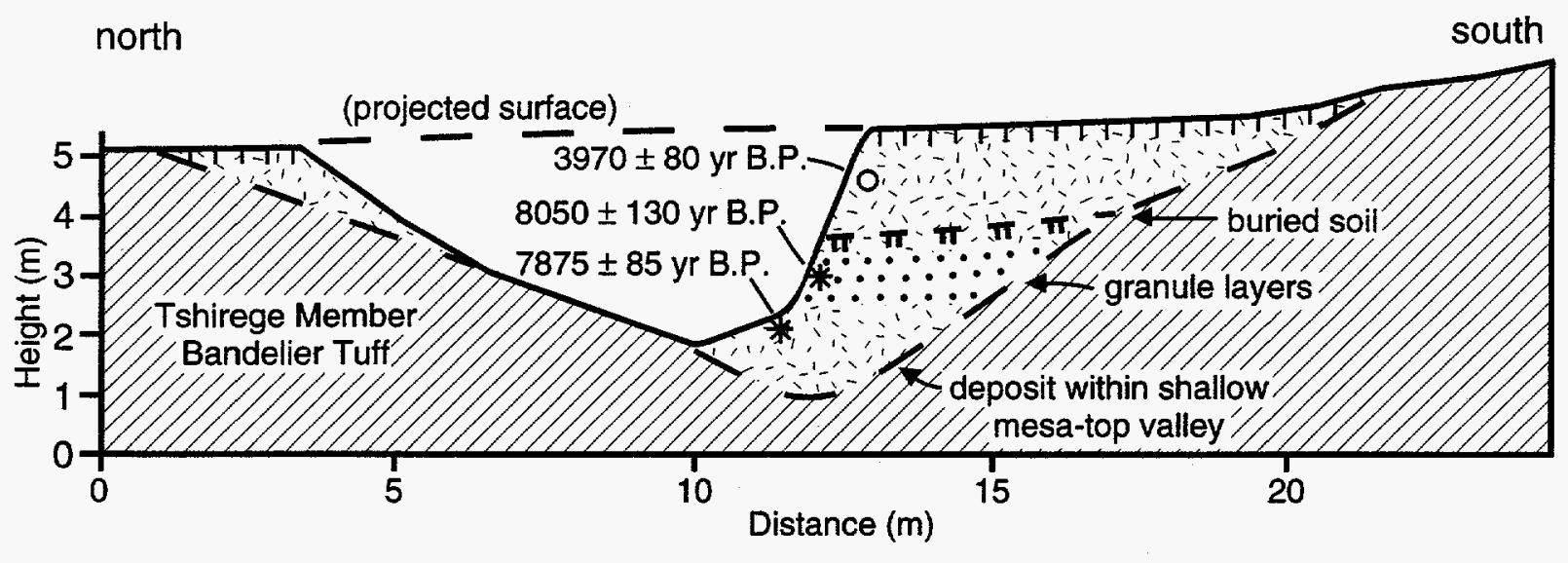

Fig. 3 


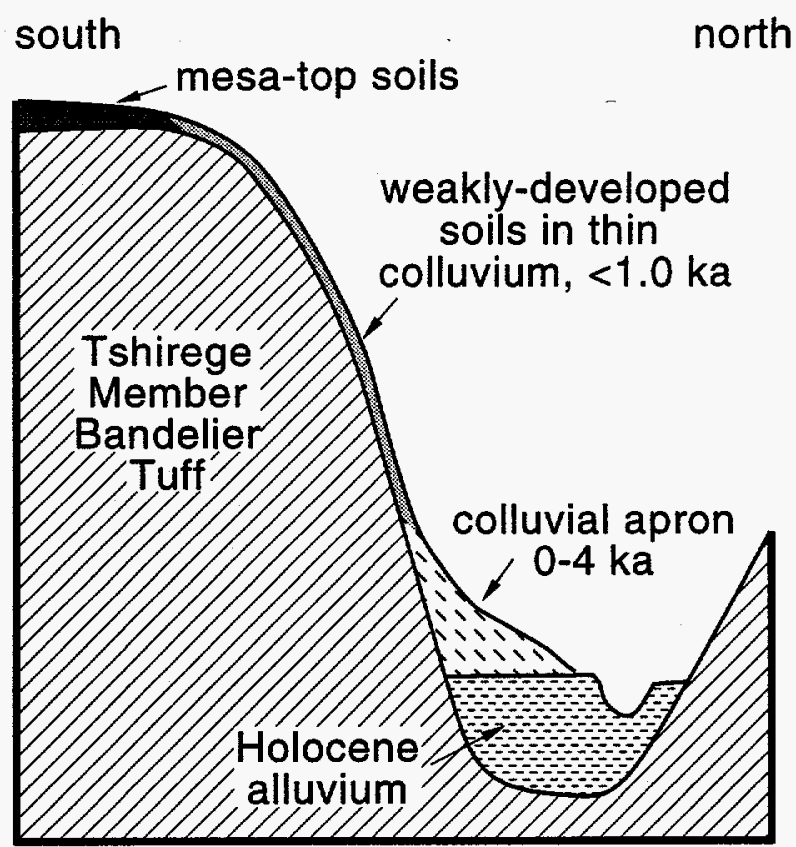

Fig. 4 


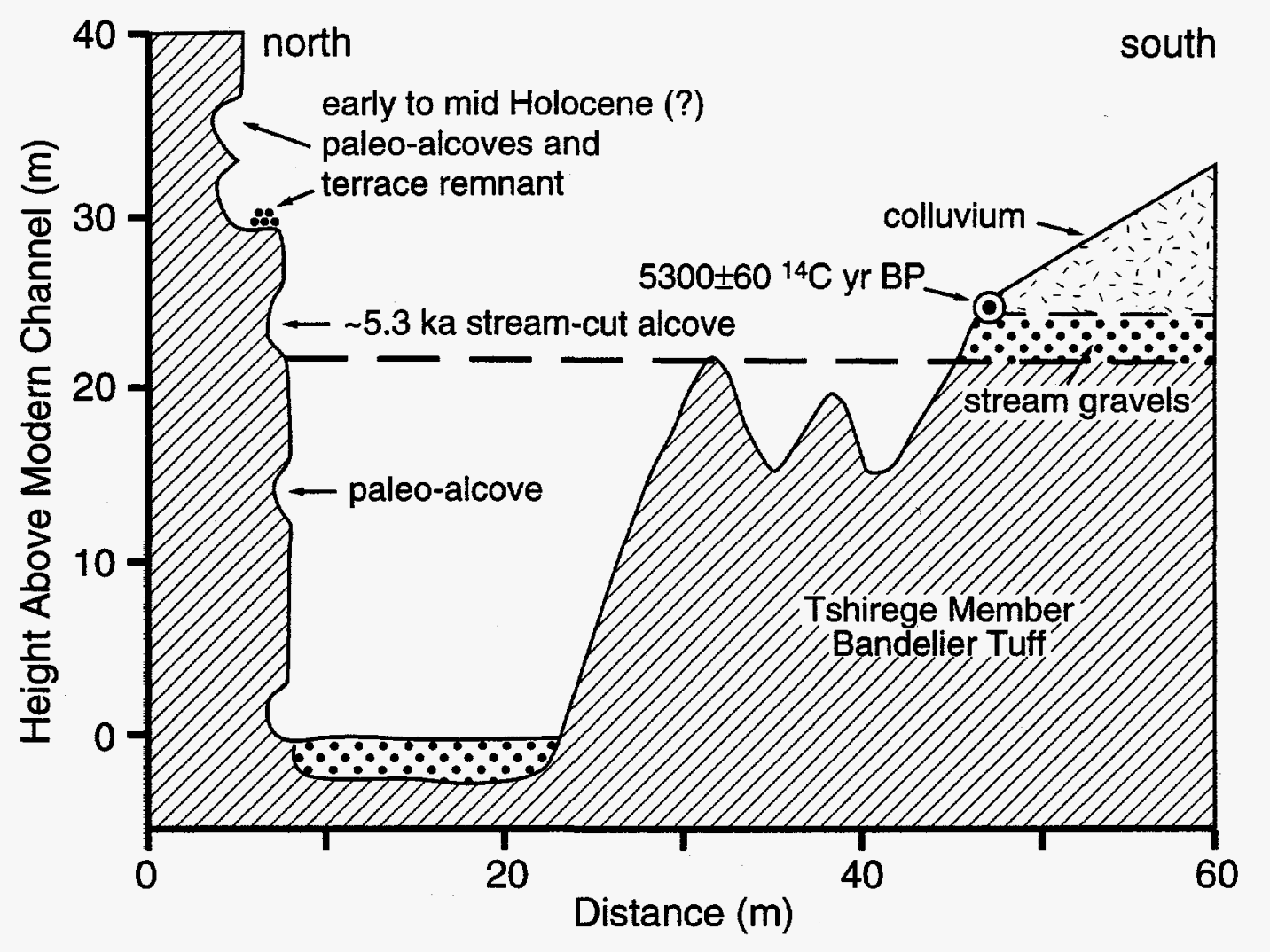

Fig 5 

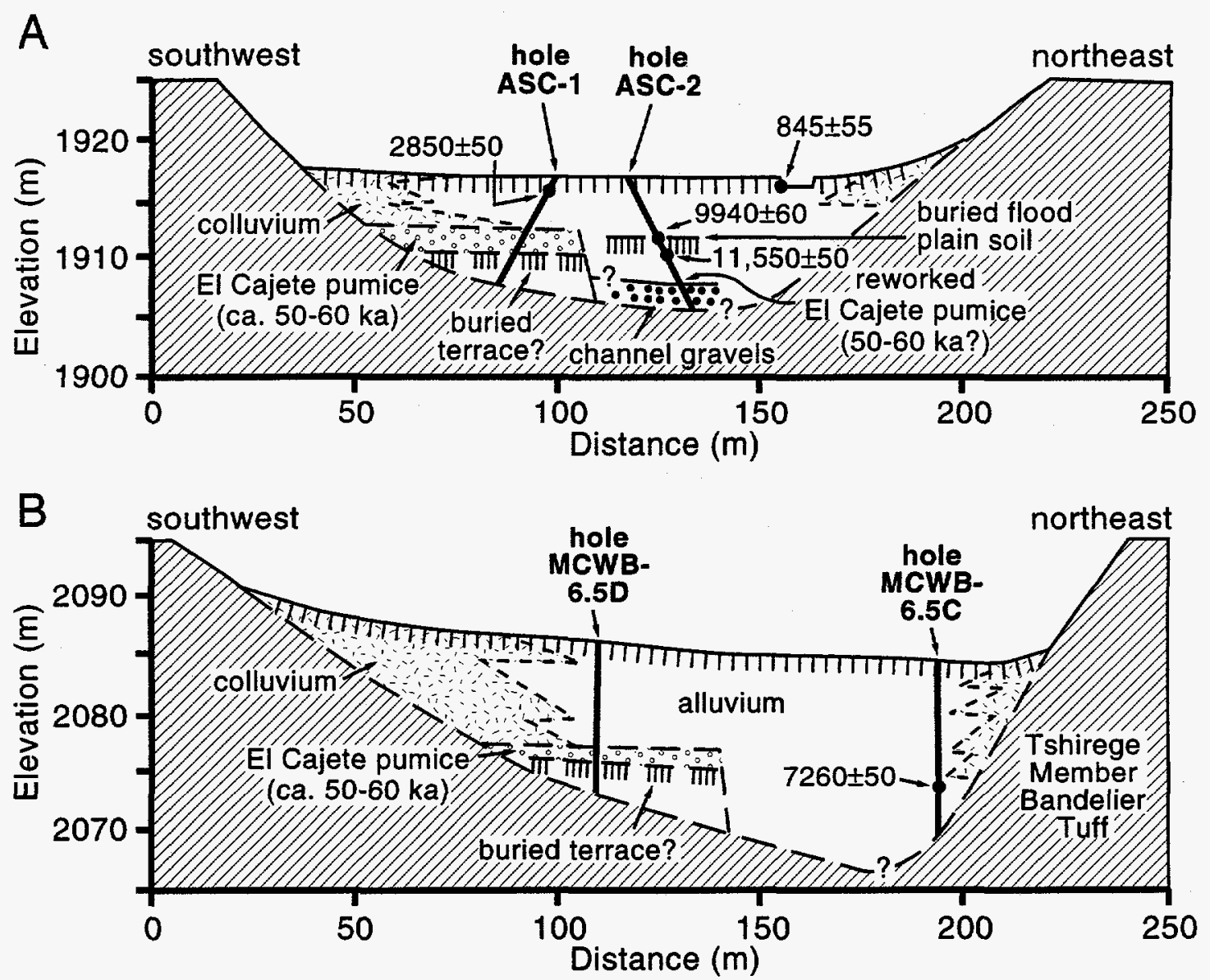

Fig 6 


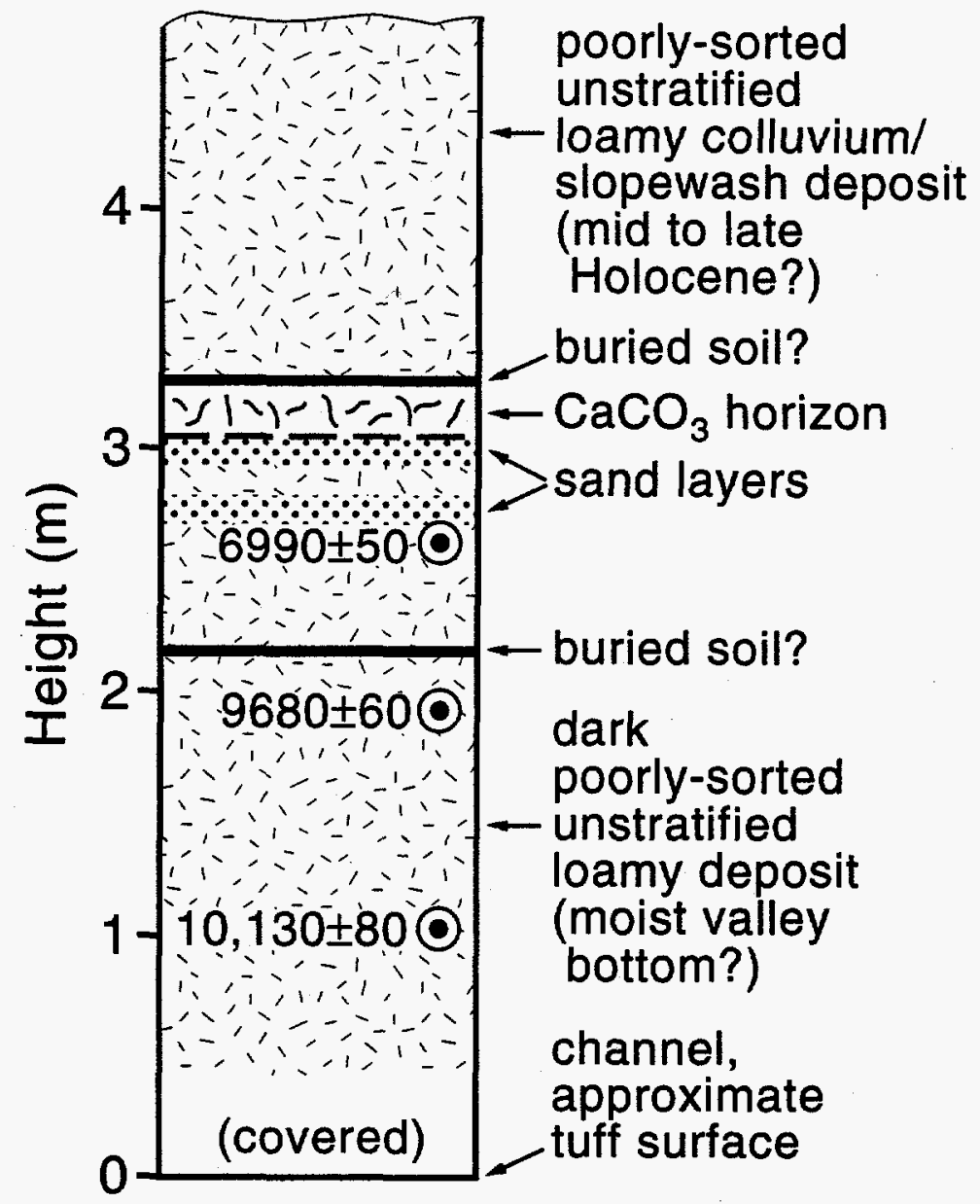

Fig. 7 


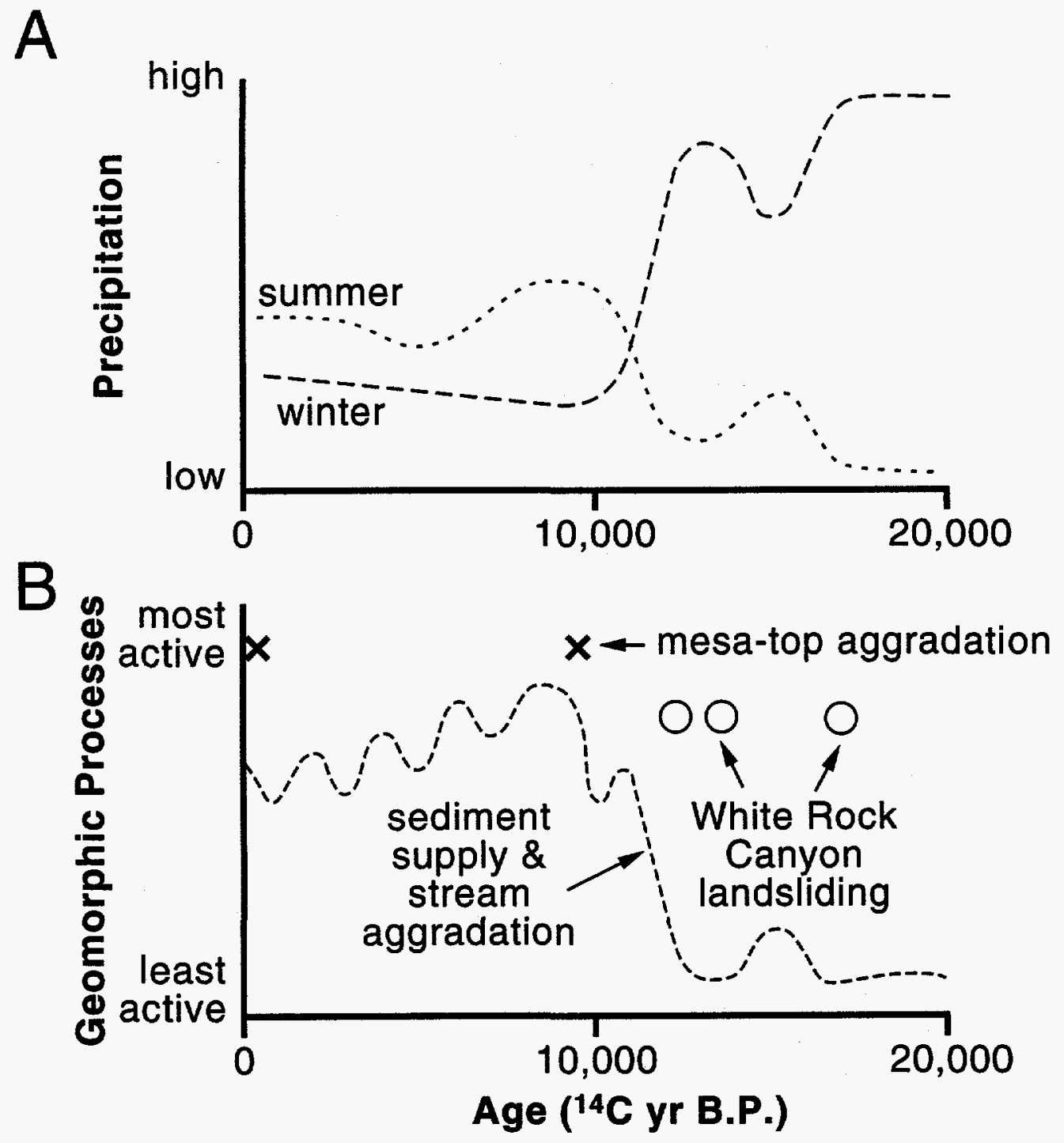

DISCLAIMER

This report was prepared as an account of work sponsored by an agency of the United States Government. Neither the United States Government nor any agency thereof, nor any of their employees, makes any warranty, express or implied, or assumes any legal liability or responsibility for the accuracy, completeness, or usefulness of any information, apparatus, product, or process disclosed, or represents that its use would not infringe privately owned rights. Reference herein to any specific commercial product, process, or service by trade name, trademark, manufacturer, or otherwise does not necessarily constitute or imply its endorsement, recommendation, or favoring by the United States Government or any agency thereof. The views and opinions of authors expressed herein do not necessarily state or reflect those of the United States Government or any agency thereof. 